Med. Mycol. J.

Vol. 52, $273-274,2011$

ISSN $2185-6486$

\title{
Photo Quiz : Basic mycology
}

どちらが Aspergillus fumigatus?

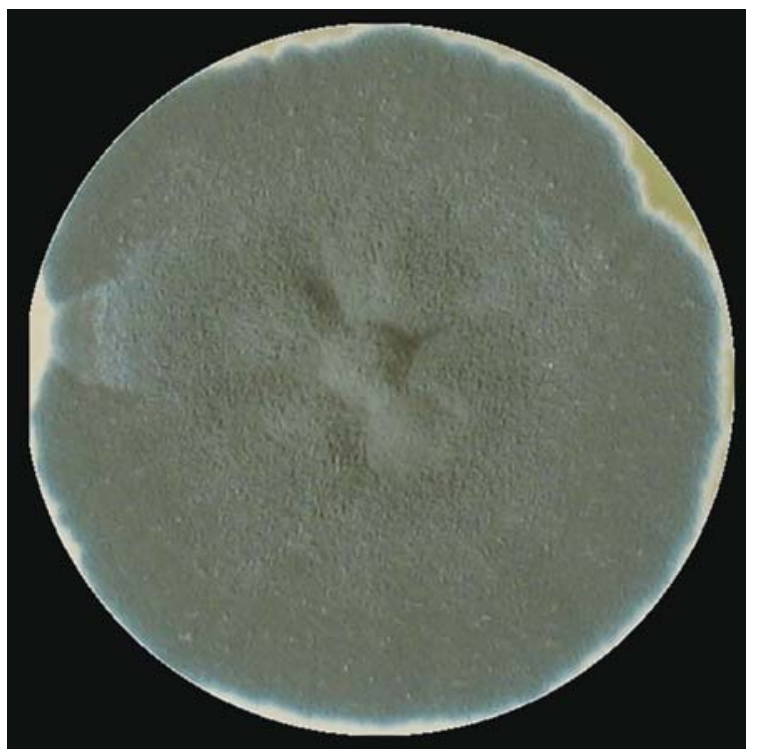

A

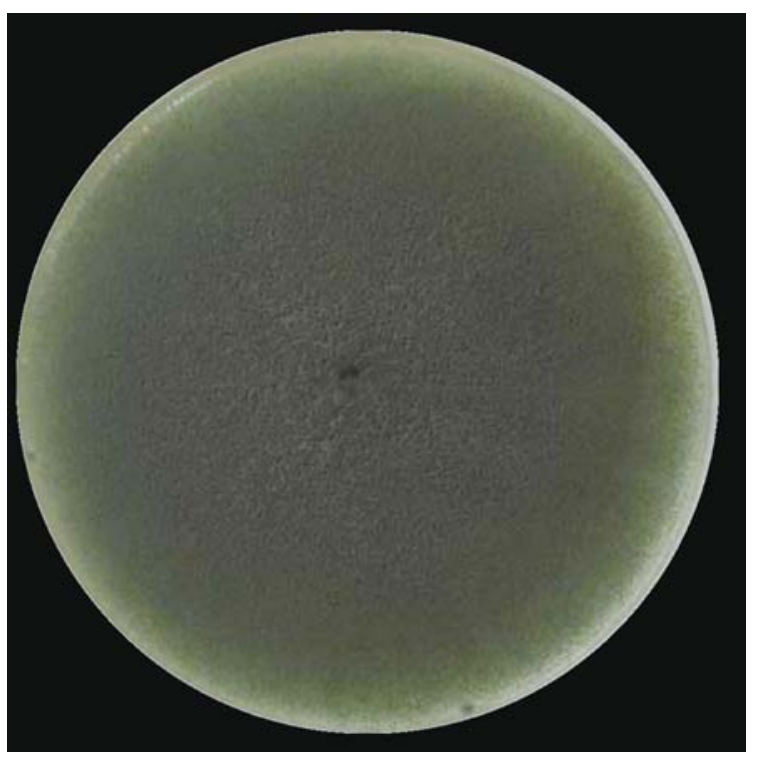

B 


\section{解答：B}

喀疹などの臨床検体から緑色の糸状菌が分離された場合，まず，Aspergillus fumigatus を想定するが，コロニーの 色調が類似した菌が環境中に棲息している. 兴れが, Penicillium spp.である.一般に, Penicillium spp.はサブローデ キストロース, ポテトデキストロース寒天 (PDA) 培地上での生育は A. fumigatus より悪く (Fig. A1, B1), 特に

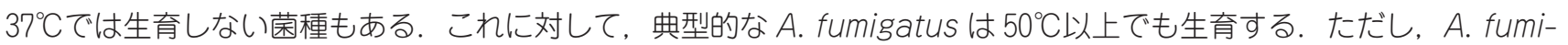
gatus と分子系統的に近縁な関連種 A. lentulus は, $45^{\circ} \mathrm{C}$ まで, A. udagawae は $42^{\circ} \mathrm{C}$ までの生育となる. 色調は, $A$. fumigatus がやや灰色を帯びた緑色になるのに対して, Penicillium spp.は多くの種が青味を帯びた緑色となる. 実体 顕微鏡で観察すると, 両者の違いは明らかで，A. fumigatus の分生子（無性の胞子）の連鎖がカラム状（Fig. B2）に なるのに対して, Penicillium spp.はほうき状（Fig. A2）になる. 顕微鏡においては, Aspergillus spp.では分生子柄 の先端が膨らみ頂のうと呼ばれるのに対し (Fig. B3), Penicillium spp.の分生子柄の先端はほとんど膨らまないこと （Fig. A3）が観察できる. コロニ一の色調だけで判断すると. A. fumigatus と Penicillium spp.は間違える可能性があ るので注意が必要である.

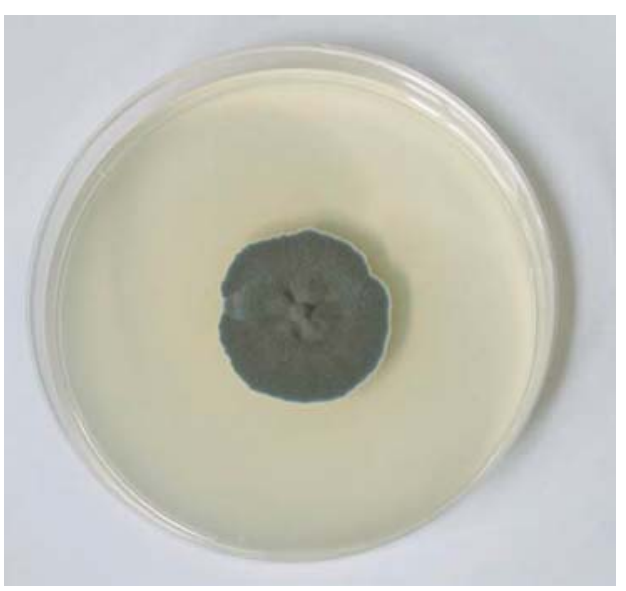

(1)

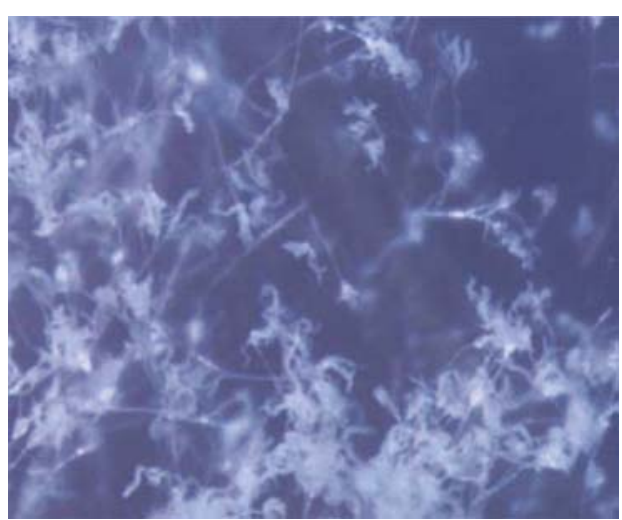

(2)

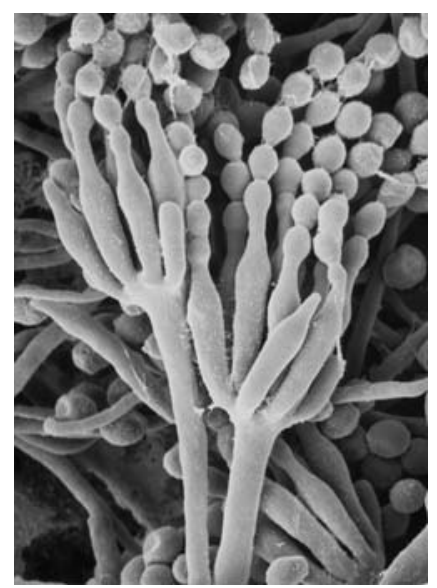

(3)

Fig. A. Penicillium implicatum.

1.コロニー (PDA, $25^{\circ} \mathrm{C}, 7$ 日間培養)，2．分生子連鎖（実体顕微鏡），3．ペニシリ（電子顕微鏡）。

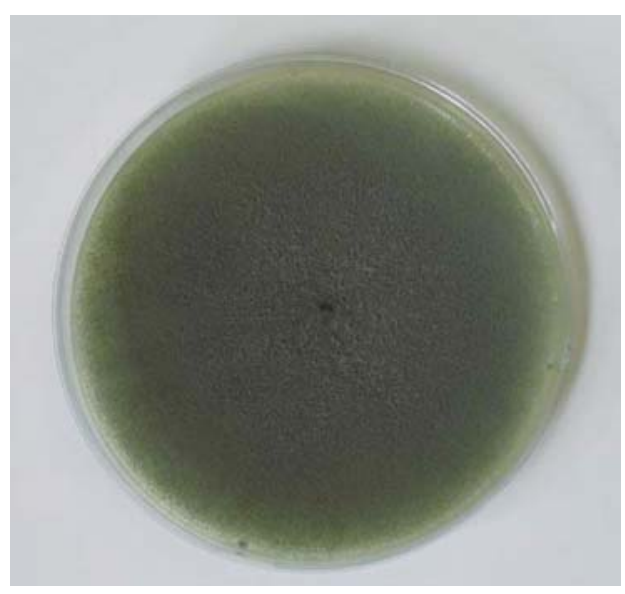

(1)

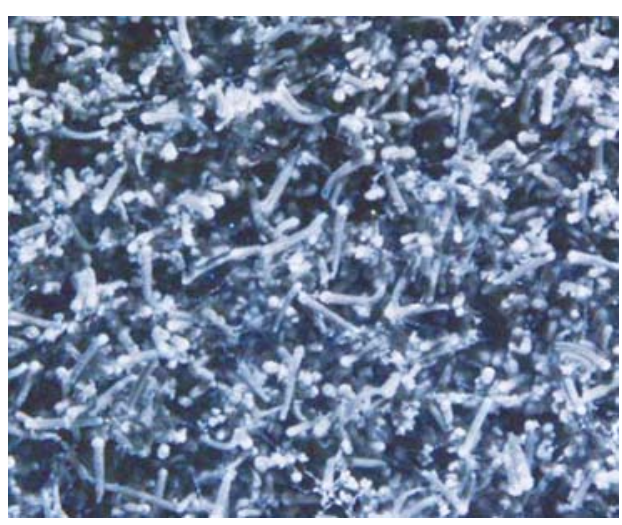

(2)

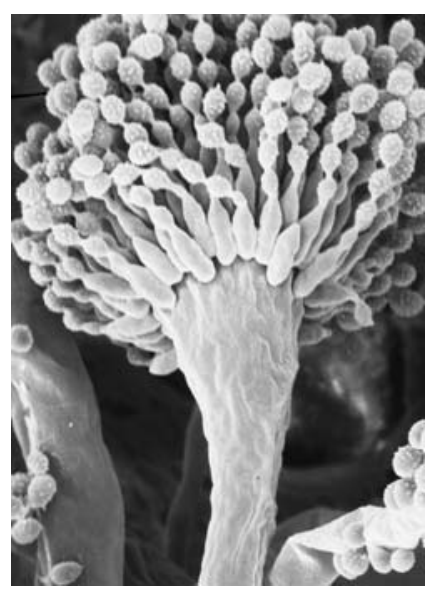

(3)

Fig. B. Aspergillus fumigatus.

1. コロニ一 ( $P D A, 25^{\circ} \mathrm{C}, 7$ 日間培養), 2. 分生子連鎖（実体顕微鏡）３．アスペルジラ（電子顕微鏡）. 